\title{
ANTI-HYPERGLYCEMIC EFFECT OF TERMINALIA CATAPPA FRUIT EXTRACT IN STREPTOZOTOCIN-INDUCED DIABETIC RATS
}

\author{
TAPAN BEHL ${ }^{1}$, ANITA KOTWANI ${ }^{*}$ \\ Department of Pharmacology, Vallabhbhai Patel Chest Institute, University of Delhi, Delhi 110007, India \\ Email: anitakotwani@gmail.com
}

Received: 08 Feb 2017 Revised and Accepted: 02 Mar 2017

\section{ABSTRACT}

Objective: To explore the anti-hyperglycemic effect of fruit extract of Terminalia catappa (Indian almond), a potential medicine from plant origin in a diabetic rat model.

Methods: Streptozotocin-induced chronic diabetic rat model was utilized in the study. Three doses of test drug, hydro-alcoholic fruit extract of Terminalia catappa in $20 \mathrm{mg} / \mathrm{kg}, 30 \mathrm{mg} / \mathrm{kg}$ and $40 \mathrm{mg} / \mathrm{kg}$ and a standard anti-diabetic drug, glibenclamide (10 mg/kg) was used. The study had a total of nine groups with eight animals in each group. Drugs were given orally every day for $12 \mathrm{w}$. Blood glucose, body weight and urine volume were measured weekly, glycosylated hemoglobin (HbA1c) was estimated at $12^{\text {th }}$ week in all groups. Data for all parameters were analyzed using one-way ANOVA repeated measures followed by Mann-Whitney test.

Results: Hydro-alcoholic fruit extract of T. catappa significantly decreased blood glucose, urine volume and increased body weight in a dosedependent manner in diabetic rats. At $12^{\text {th }}$ week, blood glucose level in control, diabetic control, glibenclamide, T. catappa (40 mg/kg) group was $96.25 \pm 2.05 \mathrm{mg} / \mathrm{dl}, 599.75 \pm 0.25 \mathrm{mg} / \mathrm{dl}, 248.25 \pm 11.45 \mathrm{mg} / \mathrm{dl}, 115.00 \pm 3.78 \mathrm{mg} / \mathrm{dl}$ respectively. Effect of T. catappa in $30 \mathrm{mg} / \mathrm{kg}$ and $40 \mathrm{mg} / \mathrm{kg} \mathrm{dose}$ was significantly more than glibenclamide. At $12^{\text {th }}$ week, HbA1c level in control, diabetic control, glibenclamide, T. catappa $(40 \mathrm{mg} / \mathrm{kg}) \mathrm{was}$ $2.94 \pm 0.33 \mathrm{mmol} / \mathrm{l}, 4.94 \pm 0.49 \mathrm{mmol} / \mathrm{l}, 3.61 \pm 0.28 \mathrm{mmol} / \mathrm{l}, 3.21 \pm 0.27 \mathrm{mmol} / \mathrm{l}$. Treatment with T. catappa $30 \mathrm{mg} / \mathrm{kg}, 40 \mathrm{mg} / \mathrm{kg}$ and glibenclamide brought back the level of HbA1c to normal levels. The addition of glibenclamide to T. catappa $(40 \mathrm{mg} / \mathrm{kg})$ did not produce any additional effect on blood glucose and HbA1c levels compared to the effect of T. catappa $(40 \mathrm{mg} / \mathrm{kg})$ in diabetic rats.

Conclusion: Terminalia catappa fruit extract exhibited a significant anti-hyperglycemic effect in diabetic rats and has a great potential to be used in diabetes.

Keywords: Anti-diabetic activity, Blood sugar, Experimental diabetes, Indian badam, Glycosylated hemoglobin

(C) 2017 The Authors. Published by Innovare Academic Sciences Pvt Ltd. This is an open access article under the CC BY license (http://creativecommons.org/licenses/by/4.0/) DOI: http://dx.doi.org/10.22159/ijpps.2017v9i4.17593

\section{INTRODUCTION}

Diabetes mellitus is a complex metabolic syndrome characterized by increased blood glucose levels, abnormal glucose and lipid metabolism, sub-clinical inflammation and increased oxidative stress. Hyperglycemia, or raised blood sugar, is a common effect of uncontrolled diabetes and is a major contributor to morbidity and mortality.

In recent years, the pharmacologic treatment of diabetes has advanced, but still an adherence to therapy and control of blood sugar remains a challenge. Herbal drugs, as alternatives to modern or allopathic medicines, are becoming popular for their cost effectiveness and comparatively fewer side effects than conventional modern medicine treatment. Furthermore, adherence to therapy amongst the diabetic population with medicines from plant origin may be better than conventional modern allopathic medicines. India has witnessed a tremendous rise in the diabetic population over the last few decades thereby earning itself the distinction of the 'Diabetic Capital of the World'. With almost 50.9 million people already suffering from diabetes mellitus this fig. is expected to reach up to 80 million by the year 2025 [1].

Terminalia catappa Linn. (Family-Combretaceae) is usually found in Maharashtra, Karnataka, Tamil Nadu, Andhra Pradesh, and Kerala, West Bengal and other warm regions of India. Terminalia catappais commonly known as Indian almond, Malabar almond and is normally consumed by a lot of people in their daily routine. Many studies have shown that apart from the nutritional benefits, Terminalia catappa plant also possessed a number of medicinal properties such as antimicrobial [2], anti-inflammatory [3], analgesic [4], wound-healing [5], anti-oxidant [6], hepatoprotective [7], anti-cancer [8] and anti-ageing activities [9]. These activities are widely owed to the virtue of the presence of certain phytochemicals in Terminalia catappa (T. catappa) such as tannins, saponins, phenols and flavonoids, carotenoids. Fruit of T. catappa has been reported to contain glucose, pentosans, corilagin, brevifolin carboxylic acid, $\beta$-carotene, cyanidin-3-glucoside, ellagic acid, gallic acid, and tannin $[10,11]$. Ellagic acid has shown to have anti-diabetic effect in diabetic rats [12]. The entire green fruit with seed inside has shown to have more phenolic content and other phytochemicals [13]. Therefore, in the present study, we have investigated the antidiabetic effect of the entire fruit of T. catappa in streptozotocininduced diabetic rats.

\section{MATERIALS AND METHODS}

\section{Hydro-alcoholic extract}

Hydro-alcoholic extract of the fruit of Terminalia catappa was obtained from standardized, GMP compliant laboratory, Pharmanza Herbal Private Limited, Gujarat with a certificate of analysis.

\section{Chemicals}

Glibenclamide and streptozotocin was obtained from Sigma Aldrich, USA. Glycosylated hemoglobin (HbA1c) ELISA kit was obtained from KINESISDx, California, USA. All other chemicals were of analytical grade.

\section{Experimental animals}

Ethical clearance for the study was obtained from Institutional Animal Ethics Committee, Vallabhbhai Patel Chest Institute, University of Delhi, Delhi (Letter no. IAEC/42/2014). Wistar rats of either sex in the weight range of 180-250 gm were obtained from Central Animal House Facility. Experimental rats were placed in metabolic cages in the animal house of Vallabhbhai Patel Chest Institute, University of Delhi, Delhi, India. Animals were housed under carefully controlled standard laboratory 
conditions of ventilation, humidity and lighting. The animals in the study were maintained at room temperature $23 \pm 1{ }^{\circ} \mathrm{C}$ with natural light and dark cycle. Animals in the study were fed with standard pellet diet and water available ad libtium. The animals were allowed a period of one week for acclimatization to laboratory conditions before the experiment.

The care of the animals was done in accordance with the guidelines of the committee for the purpose of control and supervision of experimentation on animals (CPCSEA).

\section{Methodology and study design}

Diabetes was induced in overnight fasted Wistar rats by single intraperitoneal (i. p.) injection of streptozotocin (STZ) in a dose of 45 $\mathrm{mg} / \mathrm{kg}$ in $0.1 \mathrm{M}$ citrate buffer and a $\mathrm{pH}$ of 4.5 was maintained [14]. Animals with blood glucose levels more than $300 \mathrm{mg} / \mathrm{dl}$ were considered diabetic and were included in the present study. All precautions were taken to get the real effect of test drug in diabetic condition, therefore in addition to control, diabetic control, a group treated with standard anti-diabetic drug and per se effect of test drug and standard anti-diabetic group were included and the study period was 12 w. Effect of highest dose of test drug (T. catappa) was also combined with standard anti-diabetic drug (glibenclamide) to see any additive/ potentiating effect. Permission to take eight animals (usual number permitted is six) was obtained from ethical committee. Treatment with all the drugs was started from $2^{\text {nd }}$ day till $12^{\text {th }}$ week and all the drugs were dissolved in water and were given by oral route. Rats in all the groups were fed with normal pellet diet and water ad libtium.

A study conducted by Nagappa et al., have used glibenclamide in 10 $\mathrm{mg} / \mathrm{kg}$ dose [15]. Hence, the same dose of glibenclamide was used in present study. Earlier study done with methanolic extract of Terminalia catappa (T. catappa) fruit had used $40 \mathrm{mg} / \mathrm{kg} \mathrm{p}$. o. for $3 \mathrm{w}$ and had shown significant hypoglycemic activity without any side effects in rats [15]. Therefore, the first dose selected was $40 \mathrm{mg} / \mathrm{kg}$ in the present study for T. catappa fruit extract. The next two doses were chosen after the results obtained with $40 \mathrm{mg} / \mathrm{kg}$. Effect of T. catappa on its own (per se) and glibenclamide per se was checked by giving these drugs alone in two groups of experimental animals for $12 \mathrm{w}$ as mentioned below.

Group 1: Control

Group 2: Diabetic control

Group 3: Glibenclamide $10 \mathrm{mg} / \mathrm{kg}$ per se

Group 4: Glibenclamide treatment $10 \mathrm{mg} / \mathrm{kg}$ in diabetic rats

Group 5: Terminalia catappa $40 \mathrm{mg} / \mathrm{kg}$ per se

Group 6: Terminalia catappa $40 \mathrm{mg} / \mathrm{kg}$ in diabetic rats

Group 7: Terminalia catappa $30 \mathrm{mg} / \mathrm{kg}$ in diabetic rats

Group 8: Terminalia catappa $20 \mathrm{mg} / \mathrm{kg}$ in diabetic rats

Group 9: Terminalia catappa $40 \mathrm{mg} / \mathrm{kg}$ plus glibenclamide $10 \mathrm{mg} / \mathrm{kg}$ in diabetic rats

\section{Glycemic parameters}

Blood glucose level in control, diabetic control and treatments groups were measured every $3^{\text {rd }}$ day till $3^{\text {rd }}$ week and thereafter it was measured on a weekly basis. The tail of the rat was pricked with a syringe and using electronic glucometer (Bayer breeze 2) and glucose test strips blood glucose level was measured. Glycosylated Hemoglobin A1c (HbA1c) was estimated at $12^{\text {th }}$ week in all the groups by ELISA kit of KINESISDx following manufacturer's instructions.

\section{Body weight}

Every week body weight of experimental animals was recorded. The animals in all groups-control, diabetic control and treatment groups were placed on an electronic weighing balance and their weight was taken.

\section{Urine volume}

Rats were housed in metabolic cages and their urine volume recorded every day. Average urine volume for every week was calculated.

\section{Statistical analysis}

All data are expressed as mean \pm standard error of the mean (SEM). A statistician help was taken to apply the suitable statistical test for the study. One way ANOVA with repeated measures was followed by a pairwise comparison between various treatment groups. The pairwise comparison was done using non-parametric Mann-Whitney test. Statistical analysis was done using SPSS statistics version 20 software.

\section{RESULTS}

\section{Phytochemical testing}

The phytochemical screening of hydro-alcoholic extract of Terminalia catappa fruit revealed the presence of tannins (10.50\%), alkaloids (1.95\%), saponins (19.99\%) and total polyphenols (12.01\%).

\section{Glycemic parameters}

Blood glucose level significantly increased in diabetic rats from baseline of $101.88 \pm 2.26 \mathrm{mg} / \mathrm{dl}$ to $599.75 \pm 0.25 \mathrm{mg} / \mathrm{dl}$ by $12^{\text {th }}$ week (table 1). Glibenclamide treatment significantly reduced blood glucose level $(\mathrm{p}<0.01)$ from $2^{\text {nd }}$ week onwards and the effect further increased significantly $(\mathrm{p}<0.001)$ at $12^{\text {th }}$ week, blood glucose level decreased to $248.25 \pm 11.45 \mathrm{mg} / \mathrm{dl}$ at $12^{\text {th }}$ week. The fruit extract of $T$. catappa showed dose-dependent effect on reduction of blood sugar in diabetic rats. The effect was observed from $2^{\text {nd }}$ week $(\mathrm{p}<0.01)$ and decrease in blood glucose level increased further with time. The blood glucose level was $115.00 \pm 3.78 \mathrm{mg} / \mathrm{dl}$ at $12^{\text {th }}$ week with 40 $\mathrm{mg} / \mathrm{kg}$ fruit extract and $152.38 \pm 9.97 \mathrm{mg} / \mathrm{dl}$ and $262.75 \pm 153.74$ $\mathrm{mg} / \mathrm{dl}$ with $30 \mathrm{mg} / \mathrm{kg}$ and $20 \mathrm{mg} / \mathrm{kg}$ (table 1). Effect of $T$. catappa fruit extract in the dose of $40 \mathrm{mg} / \mathrm{kg}$ on decreasing blood glucose level was statistically greater $(\mathrm{p}<0.01)$ compared to 30 $\mathrm{mg} / \mathrm{kg}$ from $4^{\text {th }}$ week till $12^{\text {th }}$ week. Effect of $40 \mathrm{mg} / \mathrm{kg}$ on blood glucose was statistically significant $(\mathrm{p}<0.01)$ than $20 \mathrm{mg} / \mathrm{kg}$ at all weeks. Terminalia catappa in $30 \mathrm{mg} / \mathrm{kg}$ dose showed significant more decrease $(\mathrm{p}<0.01)$ in blood sugar from $6^{\text {th }}$ week onwards as compared to $20 \mathrm{mg} / \mathrm{kg}$ in diabetic rats. By $12^{\text {th }}$ week in all the treatment groups though the blood glucose level was statistically lower than diabetic control rats but was still statistically higher than the normal control rats. Effect of glibenclamide on lowering blood glucose level was statistically less than $30 \mathrm{mg} / \mathrm{kg}$ and $40 \mathrm{mg} / \mathrm{kg}$ of $T$. catappa fruit. No additive effect of glibenclamide was observed when it was combined with $40 \mathrm{mg} / \mathrm{kg}$ fruit of T. catappa (table 1).

Levels of serum HbA1c significantly increased ( $4.94 \pm 0.49 \mathrm{mmol} / \mathrm{l})$ in diabetic rats as compared to normal control $(2.94 \pm 0.33 \mathrm{mmol} / \mathrm{l})$ at $12^{\text {th }}$ week. Glibenclamide, $30 \mathrm{mg} / \mathrm{kg}, 40 \mathrm{mg} / \mathrm{kg}$ dose of T. catappa fruit extract decreased the level of HbA1c to $3.61 \pm 0.28 \mathrm{mmol} / 1,3.84 \pm 0.29$ $\mathrm{mmol} / \mathrm{l}, 3.21 \pm 0.27 \mathrm{mmol} / \mathrm{l}$ and the levels were statistically same as in the control group (fig. 1). However, $40 \mathrm{mg} / \mathrm{kg}$ dose of fruit produced more reduction in the level of $\mathrm{HbA} 1 \mathrm{c}(3.21 \pm 0.27 \mathrm{mmol} / \mathrm{l})$ and was statistically lower than diabetic control rats and was statistically equal to control value. The addition of glibenclamide to $40 \mathrm{mg} / \mathrm{kg}$ dose of fruit both did not produce any further increase in effect (fig. 1).

\section{Body weight}

Body weight of diabetic rats by $12^{\text {th }}$ week was significantly lower $(127.25 \pm 2.04 \mathrm{~g})$ as compared to control rats $(406.00 \pm 2.56 \mathrm{~g})$. Glibenclamide and T. catappa fruit extract in all the three doses increased body weight in diabetic rats. At $12^{\text {th }}$ week, the body weight of glibenclamide-treated rats was $289.38 \pm 7.47 \mathrm{~g}$. The body weight in diabetic rats treated with $20 \mathrm{mg} / \mathrm{kg}, 30 \mathrm{mg} / \mathrm{kg}$ and $40 \mathrm{mg} / \mathrm{kg}$ fruit extract of $T$. catappa was $184.38 \pm 2.20 \mathrm{~g}, 231 \pm 2.49 \mathrm{~g}, 309.63 \pm 9.11 \mathrm{~g}$ respectively. Terminalia catappa in the dose of $20 \mathrm{mg} / \mathrm{kg}$ significantly increased body weight in diabetic rats at $8^{\text {th }}$ week $(\mathrm{p}<0.05)$; increase in body weight increased with time, i.e., at $10^{\text {th }}$ and at $12^{\text {th }}$ week $(\mathrm{p}<0.01)$. However, with $30 \mathrm{mg} / \mathrm{kg}$ of $T$. catappa, an increase in body weight started at $4^{\text {th }}$ week $(\mathrm{p}<0.01)$ and this increase remained till $12^{\text {th }}$ week. Similarly, $40 \mathrm{mg} / \mathrm{kg}$ dose of T. catappa showed an increase in body weight at $4^{\text {th }}$ week $(\mathrm{p}<0.01)$ and the effect on body weight was observed till $12^{\text {th }}$ week in diabetic rats. Administration of T. catappa 40 $\mathrm{mg} / \mathrm{kg}$ plus glibenclamide in diabetic rats showed a statistically equal effect in increasing body weight when compared with T. catappa 40 $\mathrm{mg} / \mathrm{kg}$ alone though numerically it was more. Terminalia catappa produced a dose-dependent effect on body weight in diabetic rats. 
Effect of $40 \mathrm{mg} / \mathrm{kg}$ was statistically more $(\mathrm{p}<0.01)$ compared to 30 $\mathrm{mg} / \mathrm{kg}$ and $20 \mathrm{mg} / \mathrm{kg}$ at all weeks. Similarly, the effect of $30 \mathrm{mg} / \mathrm{kg}$ of T. catappa was statistically significant than $20 \mathrm{mg} / \mathrm{kg}$ throughout the study period on body weight in diabetic rats After $12 \mathrm{w}$ of treatment with all the drugs body weight was still statistically lower than the normal control rats (fig. 2).

Table 1: Effect of different doses of Terminalia catappa fruit extract and glibenclamide on blood glucose (mg/dl) in diabetic rats

\begin{tabular}{|c|c|c|c|c|c|c|c|}
\hline & $\begin{array}{l}\text { Normal } \\
\text { Control }\end{array}$ & $\begin{array}{l}\text { Diabetic } \\
\text { Control }\end{array}$ & $\begin{array}{l}\text { Glibenclamide } \\
10 \mathrm{mg} / \mathrm{kg}\end{array}$ & $\begin{array}{l}\text { T. catappa fruit } \\
\text { extract } 40 \mathrm{mg} / \mathrm{kg}\end{array}$ & $\begin{array}{l}\text { T. catappa fruit } \\
\text { extract } 30 \mathrm{mg} / \mathrm{kg}\end{array}$ & $\begin{array}{l}\text { T. catappa fruit } \\
\text { extract } 20 \mathrm{mg} / \mathrm{kg}\end{array}$ & $\begin{array}{l}\text { T. catappa fruit } 40 \\
\text { mg/kg+Glibenclamide }\end{array}$ \\
\hline $0 \mathrm{~W}$ & $97.62 \pm 2.24$ & $101.88 \pm 2.26$ & $99.38 \pm 2.21$ & $99.5 \pm 2.41$ & $104.25 \pm 1.67$ & $97.88 \pm 2.72$ & $99.00 \pm 0.85$ \\
\hline $48 \mathrm{H}$ & $96.25 \pm 2.40$ & $556.75 \pm 16.15^{\# \#}$ & $573.25 \pm 13.56$ & $514.38 \pm 30.22$ & $524.5 \pm 22.27$ & $535.75 \pm 15.90$ & $565.13 \pm 19.57$ \\
\hline $2 \mathrm{~W}$ & $94.63 \pm 2.01$ & $591.5 \pm 3.50^{\# \#}$ & $501.88 \pm 15.25^{* *}$ & $443.75 \pm 10.17^{* *,+}$ & $498.13 \pm 20.00^{* *}$ & $523.75 \pm 14.24 * *$,aа & $402.25 \pm 16.02^{* *+++}$ \\
\hline $4 \mathrm{~W}$ & $91.88 \pm 1.11$ & $594.5 \pm 2.85^{\# \#}$ & $446.88 \pm 17.72^{* *}$ & $338.75 \pm 11.41^{* *+++}$ & $473.75 \pm 19.93^{* * \text {,aа }}$ & $484.13 \pm 15.69 * *$,aа & $291.13 \pm 18.03^{* *,++}$ \\
\hline $6 \mathrm{~W}$ & $95.13 \pm 1.60$ & $598.5 \pm 1.24 \# \#$ & $396.38 \pm 16.12^{* *}$ & $250 \pm 13.50^{* *,++}$ & $384.88 \pm 7.95^{* * \text {,аa }}$ & $449.13 \pm 14.83^{* *, a a, b b,+}$ & $206.13 \pm 16.03^{* *,++}$ \\
\hline $8 \mathrm{~W}$ & $92.5 \pm 1.93$ & $596.25 \pm 2.91 \# \#$ & $339.63 \pm 17.85^{* *}$ & $171.75 \pm 7.51 * *,++$ & $283.63 \pm 16.11^{* * \text {,aа }}$ & $392.13 \pm 14.00^{* *, a a, b b,+}$ & $167.87 \pm 9.92^{* *,++}$ \\
\hline $10 \mathrm{~W}$ & $92.75 \pm 2.02$ & $596.5 \pm 2.97 \# \#$ & $299.38 \pm 16.18^{* *}$ & $137.25 \pm 4.73^{* *,++}$ & $219.5 \pm 13.05^{* *, a a,++}$ & $337 \pm 12.59 * *$,aa,bb & $135.37 \pm 7.10^{* *,++}$ \\
\hline $12 \mathrm{~W}$ & $96.25 \pm 2.05$ & $599.75 \pm 0.25 \# \# \#$ & $248.25 \pm 11.45^{* * *, \# \#}$ & $115.00 \pm 3.78^{* * *,++, \# \#}$ & 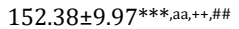 & $267.25 \pm 15.74 * * *, \mathrm{aa}, \mathrm{bb}, \# \#$ & $110.75 \pm 2.99^{* * *,++\# \# ~}$ \\
\hline
\end{tabular}

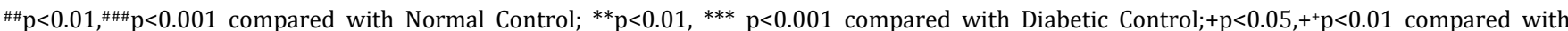
Glibenclamide treatment; ${ }^{\text {aap}}<0.01$ compared with T. catappa fruit extract $40 \mathrm{mg} / \mathrm{kg}$; ${ }^{\text {bb }} \mathrm{p}<0.01$ compared with $T$. catappa fruit extract $30 \mathrm{mg} / \mathrm{kg}$. GbGlibenclamide. Differences were analyzed by One way ANOVA followed by Mann-Whitney test.

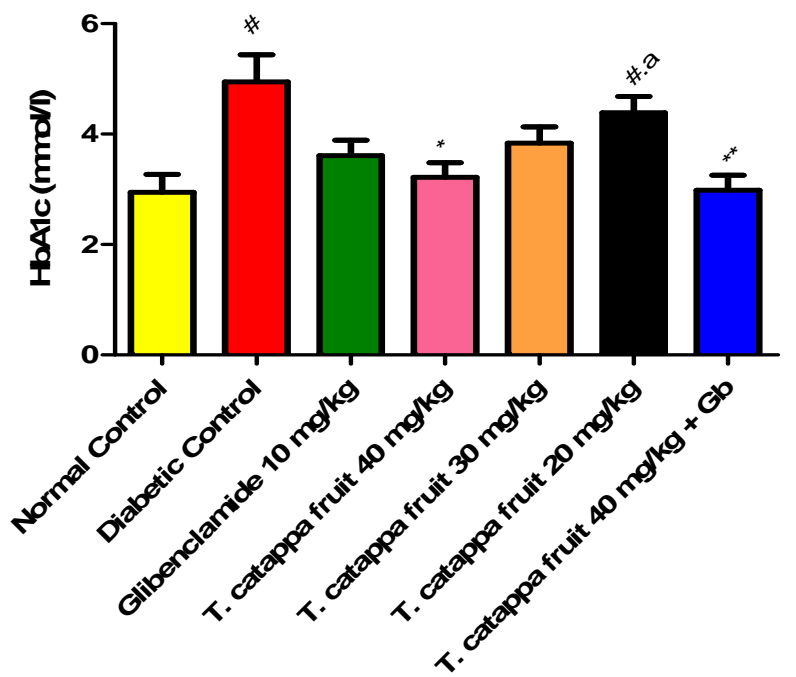

Fig. 1: Effect of different doses of Terminalia catappa fruit extract and glibenclamide on HbA1c (mmol/l) in diabetic rats at 12th week study period. ( $\#$ p $<0.05$ compared with Normal Control; ${ }^{*}$ p $<0.05,{ }^{* *} p<0.01$ compared with Diabetic Control; ${ }^{\text {ap}}<0.05$ compared with T. catappa fruit extract $40 \mathrm{mg} / \mathrm{kg}$. Gb-Glibenclamide. Differences were analyzed by One-way ANOVA followed by Mannwhitney test)

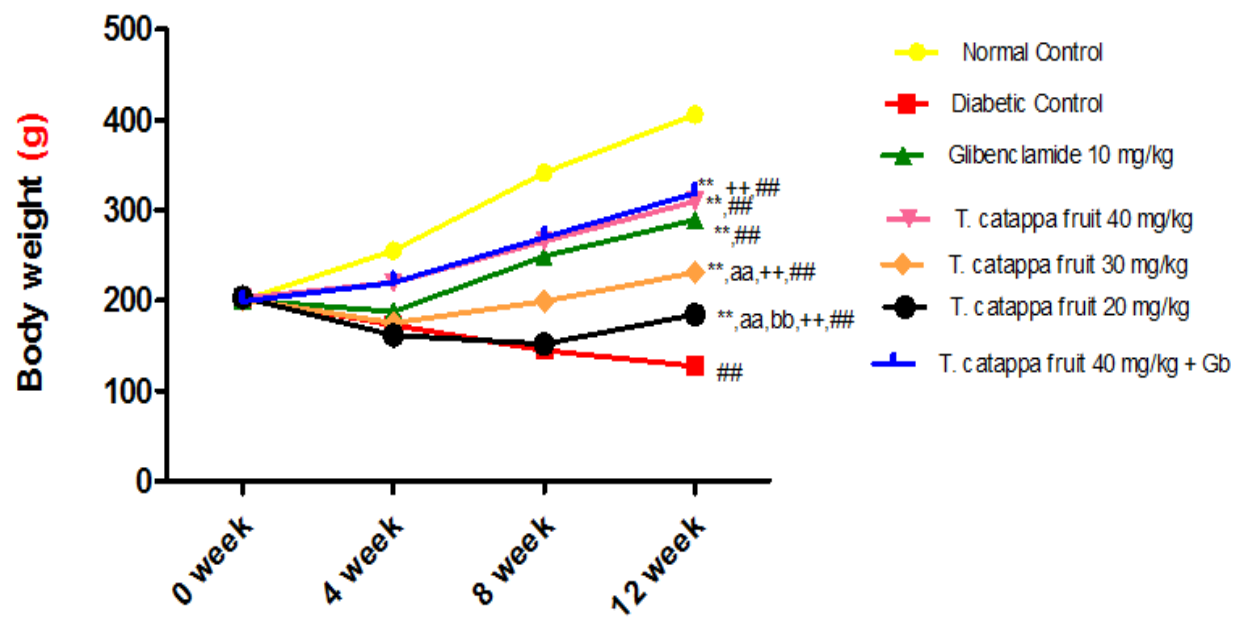

Fig. 2: Effect of different doses of Terminalia catappa fruit extract and glibenclamide on body weight (g) in diabetic rats. (\#\#p<0.01 compared with Normal Control; ${ }^{* *} \mathbf{p}<0.01$ compared with Diabetic Control; $+{ }^{+} \mathbf{p}<0.01$ compared with glibenclamide treatment; aap $<0.01$ compared with $T$. catappa fruit extract $40 \mathrm{mg} / \mathrm{kg}$; bb $<<0.01$ compared with $T$. catappa fruit extract $30 \mathrm{mg} / \mathrm{kg}$. Gbglibenclamide. Differences were analyzed by One-way ANOVA followed by Mann-whitney test) 


\section{Urine volume}

Induction of diabetes in experimental animals produced a significant increase in urine volume from $2^{\text {nd }}$ week onwards. By $12^{\text {th }}$ week, the urine volume in diabetic control rats was $76.84 \pm 1.10 \mathrm{ml}$ as compared to $1.63 \pm 0.29 \mathrm{ml}$ in control rats (fig. 3 ).

Treatment with glibenclamide decreased urine volume significantly from $2^{\text {nd }}$ week onwards, and by $12^{\text {th }}$ week, urine volume decreased to $21.59 \pm 0.50 \mathrm{ml}$. Terminalia catappa fruit extract in diabetic rats produced significant (from $2^{\text {nd }}$ week onwards) dose-dependent reduction with $20 \mathrm{mg} / \mathrm{kg}, 30 \mathrm{mg} / \mathrm{kg}$ and $40 \mathrm{mg} / \mathrm{kg}$ in urine volume viz. $21.93 \pm 0.21 \mathrm{ml}, 10.63 \pm 0.42 \mathrm{ml}$ and $6.48 \pm 0.61 \mathrm{ml}$ respectively. Effect of $40 \mathrm{mg} / \mathrm{kg}$ of $T$. catappa was significantly more than $20 \mathrm{mg} / \mathrm{kg}$ and $30 \mathrm{mg} / \mathrm{kg}$ and effect of $30 \mathrm{mg} / \mathrm{kg}$ was more than $20 \mathrm{mg} / \mathrm{kg}$ of $T$. catappa fruit extract on the reduction of urine volume.

Effect of $30 \mathrm{mg} / \mathrm{kg}$ and $40 \mathrm{mg} / \mathrm{kg}$ dose of hydroalcoholic fruit extract was statistically greater than glibenclamide. Administration of $T$. catappa $40 \mathrm{mg} / \mathrm{kg}$ plus glibenclamide in diabetic rats showed a significant decrease $(\mathrm{p}<0.01)$ in urine volume from $2^{\text {nd }}$ week onwards till $12^{\text {th }}$ week when compared with $T$. catappa $40 \mathrm{mg} / \mathrm{kg}$ alone (fig. 3).

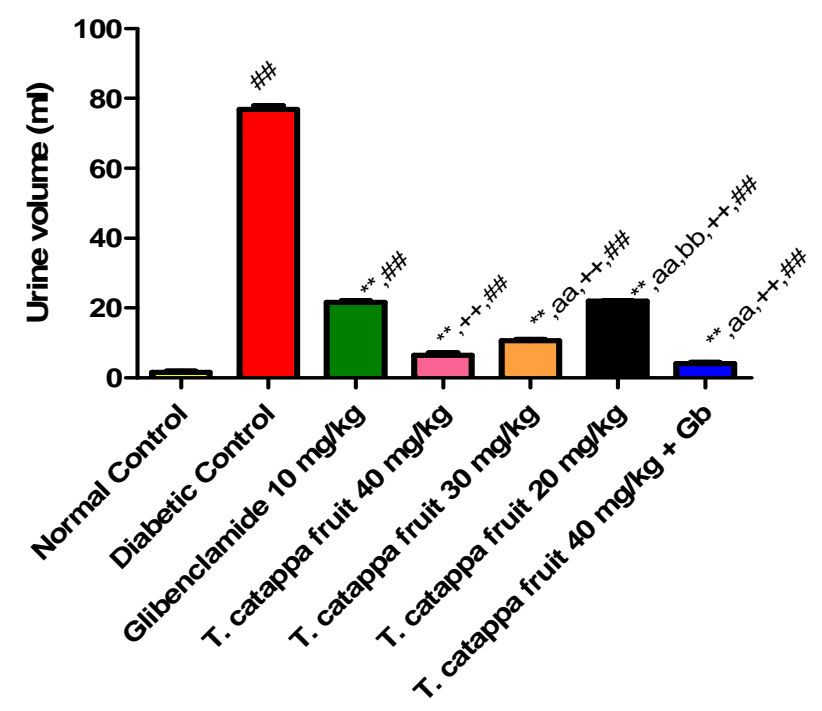

Fig. 3: Effect of different doses of Terminalia catappa fruit extract and glibenclamide on urine volume (ml) in diabetic rats. $\left(\# \# \mathbf{p}<0.01\right.$ compared with Normal Control; ${ }^{* *} \mathbf{p}<0.01$ compared with Diabetic Control; $+^{+} \mathbf{p}<0.01$ compared with Glibenclamide treatment; aap $<0.01$ compared with $T$. catappa fruit extract $40 \mathrm{mg} / \mathrm{kg}$; ${ }^{\text {bb }} \mathbf{p}<0.01$ compared with $T$. catappa fruit extract $30 \mathrm{mg} / \mathrm{kg}$. Gb-Glibenclamide. Differences were analyzed by One-way ANOVA followed by Mann-whitney test)

\section{DISCUSSION}

The prevalence of diabetes mellitus is increasing at an alarming rate and the development of medicines from the natural origin or functional food are need of the hour as they are associated with less side effects and the compliance to medication could be more. Adherence to therapy is important as diabetes is a chronic disease and requires long-term therapy for control of blood sugar. Therefore, we have used a chronic diabetic rat model of $12 \mathrm{w}$. Earlier study conducted with Terminalia catappa was for three weeks' duration [15]. The present study showed the anti-hyperglycemic effect of hydro-alcoholic fruit extract of Terminalia catappa in streptozotocin-induced diabetic rats. Streptozotocin leads to the destruction of pancreatic $\beta$-cells by causing alkylation of DNA leading to insufficient production of insulin thereby increasing blood glucose levels $[16,17]$. In our study, blood glucose level in the diabetic control group remained significantly high as compared to control group throughout the study period of $12 \mathrm{w}$.

Glibenclamide, a standard anti-diabetic drug reduced blood glucose level in diabetic rats. Similar results with glibenclamide are reported in previous studies indicating the reduced blood glucose level in diabetic rats which was suggested to be due to a stimulatory effect on the initial release of insulin and inhibition of ATP-sensitive $\mathrm{K}^{+}$channels $[18,19]$.

Hydro-alcoholic fruit extract of T. catappa in three doses $(20 \mathrm{mg} / \mathrm{kg}$, $30 \mathrm{mg} / \mathrm{kg}$ and $40 \mathrm{mg} / \mathrm{kg}$ ) showed a significant dose-dependent reduction in blood glucose level compared to diabetic control rats. Terminalia catappa (T. catappa) contains alkaloids, flavonoids, tannins, saponosides, sterols, carbohydrates, proteins, carotenoids ( $\beta$-carotene), fat, vitamins, triterpenes, thiocyanates, cardiac glycosides, cyanogenic glycosides and para-hydroxybenzoic acid [10, 11, 20]. Earlier, Nagappa et al. (2011) have shown the anti- hyperglycemic effect of methanolic extract of T. catappa fruit and have postulated the role of $\beta$-carotene in causing regeneration of pancreatic beta cells in Wistar rats [15]. Polyphenols have shown antihyperglycemic effect by protecting $\beta$-cell function and promoting insulin action and secretion $[21,22,23]$. Phytoconstituents like flavonoids, tannins and triterpenoids have shown inhibitory effect on $\alpha$-glucosidase and $\alpha$-amylase activity thereby inhibiting intestinal $\mathrm{Na}^{+}$dependent glucose transporters (SGLT1 and SGLT2) leading to decreased digestion and intestinal absorption of dietary carbohydrates $[24,25,26]$. A study conducted by Salehi et al. (2013) reported the anti-diabetic effect of ten plants containing phenols in different extracts by inhibition of $\alpha$ glucosidase and $\alpha$-amylase activity in diabetic rats [27]. Thus, in the present study, the anti-hyperglycemic activity of hydro-alcoholic fruit extract of $T$. catappa may be attributed due to the presence of high concentration of tannins and other polyphenols that are known to regenerate pancreatic $\beta$ cells, protect $\beta$ cell function and promote insulin action, secretion and decrease in absorption thereby decreasing blood glucose levels.

It is well evident that glycosylated hemoglobin (HbA1c) level is increased in diabetic condition $[28,29]$. In the present study, diabetic control rats had significantly higher HbA1c level compared to control rats. Glibenclamide treatment in diabetic rats reduced $\mathrm{HbA1c}$ levels and is similar to results obtained in previous studies [30, 31]. In the present study, treatment of diabetic rats with fruit extract of $T$. catappa reduced HbA1c levels significantly compared to diabetic control rats. Sampath and Mani, (2015) have reported reduced HbA1c level in diabetic rats treated with tannin enriched extract [32]. Polyphenols have also shown to reduce digestion and intestinal absorption of dietary carbohydrates and promote insulin secretion [33]. Our test drug, hydroalcoholic fruit extract of T. catappa have a 
high content of tannins and other polyphenols which may be responsible for decreasing the higher $\mathrm{HbA1}$ c level in diabetic rats.

In our study, body weight was significantly decreased in diabetic control rats compared to control rats. Diabetes produced a significant reduction in body weight in rats due to loss of tissue proteins and increased muscle wasting in diabetic condition [34, 35]. Treatment with glibenclamide in diabetic rats has been shown to reduce blood glucose and prevention of muscle wasting which probably is responsible for the increase in body weight [32]. Treatment of diabetic rats with hydroalcoholic fruit extract of T. catappa in different doses significantly increased body weight compared to diabetic control rats. Our test drug hydro-alcoholic fruit extract of T. catappa contain tannins and other polyphenols which decrease blood glucose level and are postulated to be responsible for increasing body weight in diabetic rats. Sampath and Mani, (2015) have reported increased body weight in diabetic rats treated with tannin enriched extract of Terminalia chebula and Punica granatum [32].

Excessive urination is a symptom of diabetes and is due to the inability of the renal tubules to absorb glucose filtered in the glomeruli leading to osmotic diuresis [36]. Similarly, in our study urine volume was significantly increased in diabetic rats compared to control rats. Glibenclamide treated diabetic rats showed a significant reduction in urine volume compared to diabetic control rats and the results of the present study are in agreement with the studies done earlier [37, 38]. Dubey et al. (2013) have shown that treatment of diabetic rats with oleanolic acid decreased blood glucose level and increased glomerular filtration rate [39].

Diniz et al. (2012) have shown that saponins of Ampelozizyphus amazonicus reduce renal atrial natriuretic peptides (ANP) and/or have a stimulatory effect on renal ATP ase activity and reduce urine volume in rats [40]. Hydro-alcoholic fruit extract of T. catappa in 20 $\mathrm{mg} / \mathrm{kg}, 30 \mathrm{mg} / \mathrm{kg}$ and $40 \mathrm{mg} / \mathrm{kg}$ dose showed a significant dosedependent reduction in urine volume compared to diabetic control rats and could be due to the presence of polyphenols like tannins, saponins and flavonoids which reduce blood glucose levels.

\section{CONCLUSION}

The hydro-alcoholic fruit extract of Terminalia catappa (Indian almond) showed a reduction in blood glucose, HbA1c, urine volume and an increase in body weight in diabetic rats. Anti-hyperglycemic effect of fruit extract of T. catappa can be attributed to the presence of tannins, saponins and polyphenols which could be responsible for its anti-diabetic effect in rats. Recently the use of medicines from plant origin and functional foods has been considered as a new approach in the prevention and management of diabetes and its complications. Our test drug, Indian almond fruit (Terminalia catappa) has a great potential as an anti-diabetic drug. Further work is warranted to explore the mechanism of action of this potential anti-diabetic drug which will give additional evidence to use Terminalia catappa for the treatment of diabetes and diabetesinduced complications.

\section{ACKNOWLEDGEMENT}

The authors would like to acknowledge the financial support(Project number Z.28015/13/2013-HPC (EMR-AYUSH-A) for the project (part of the work is reported here) received from Central Council for Research in Ayurveda and Siddha (CCRAS), Ministry of AYUSH, Government of India.

\section{AUTHOR CONTRIBUTION}

Prof. Anita Kotwani conceived the idea and designed the protocol of the study. Prof. Kotwani is the Principal Investigator of the project. Mr. Tapan Behl is Senior Research Officer on the project, conducted the experiments and drafted the manuscript. Prof. Kotwani critically revised the manuscript. Both the authors have approved the final version of the manuscript.

\section{CONFLICT OF INTERESTS}

The authors declare no conflict of interest

\section{REFERENCES}

1. Global Reports on Diabetes. World Health Organisation (WHO); 2016.

2. Nair R, Chanda S. Antimicrobial activity of Terminalia catappa, Manilkara zapota and Piper betel Leaf Extract. Indian J Pharam Sci 2008;70 Suppl 3:390-3.

3. Venkatalakshmi P, Brindha P, Vellingiri V. In vitro antioxidant and anti-inflammatory studies on bark, wood and fruits of Terminalia catappa L. Int J Phytomed 2015;7 Suppl 3:246-53.

4. Annegowda HV, Mordi MN, Ramanathan S, Mansor SM. Analgesic and antioxidant properties of ethanolic extract of Terminalia catappa L. leaves. Int J Pharmacol 2010;6 Suppl 6:910-5.

5. Khan AA, Kumar V, Singh BK, Singh R. Evaluation of wound healing property of Terminalia catappa on excision wound models in Wistar rats. Drug Res 2014;64 Suppl 5:225-8.

6. Chyaua CC, Kob PT, Mau JL. Antioxidant properties of aqueous extracts from Terminalia catappa leaves. LWT 2006;39 Suppl 10:1099-108.

7. Gao J, Tang X, Dou H, Fan Y, Zhao X, Xu Q. Hepatoprotective activity of Terminalia catappa L. leaves and its two triterpenoids. J Pharm Pharmacol 2004;56:1449-55.

8. Pandya NB, Tigari P, Dupadahalli K, Kamurthy H, Nadendla RR. Antitumor and antioxidant status of Terminalia catappa against Ehrlich ascites carcinoma in Swiss albino mice. Indian J Pharmacol 2013;45 Suppl 5:464-9.

9. Satardekar KV, Deodhar MA. The anti-ageing ability of Terminalia species with special reference to hyaluronidase, elastase inhibition and collagen synthesis in vitro. Int J Pharmacogn Phytochem Res 2010;2:30-4.

10. Anand AV, Divya N, Kotti PP. An updated review of Terminalia catappa. Pharmacogn Rev 2015;9:93-8.

11. Koffi N, Yvette FNB, Noel ZG. Effect of aqueous extract of Terminalia catappa leaves on the glycaemia of rabbits. J Appl Pharm Sci 2011;1:59-64.

12. Malini P, Kanchana G, Rajadurai M. Antidiabetic efficacy of ellagic acid in streptozotocin induced diabetes mellitus in albino Wistar rats. Asian J Pharm Clin Res 2011;4 Suppl 3:124-8.

13. Wiejeratne S, Zaid AM, Shahidi F. Antioxidant polyphenols in almonds and its coproducts. J Agric Food Chem 2006;54 Suppl 2:312-8.

14. Gupta SK, Kumar B, Nag TC, Agarwal SS, Agarwal R, Agarwal P, et al. Curcumin prevents experimental diabetic retinopathy in rats through hypoglycaemic, antioxidant and antiinflammatory mechanisms. J Ocul Pharmacol Ther 2011;27 Suppl 2:123-30.

15. Nagappa AN, Thakurdesai PA, Rao NV, Singh J. Antidiabetic activity of Terminalia catappa Linn fruits. J Ethnopharmacol 2003;88:45-50.

16. Mahimainathan L, Das F, Venkatesan B, Choudhury GG. Mesangial cell hypertrophy by high glucose is mediated by downregulation of the tumor suppressor PTEN. Diabetes 2006;55:2115-25.

17. Rao NK, Nammi S. Antidiabetic and renoprotective effects of the chloroform extract of Terminalia chebula Retz. seeds in streptozotocin-induced diabetic rats. BMC Complementary Altern Med 2006;6:1-6.

18. Erejuwa 00, Sulaiman SA, Abdul Wahab MS, Kuttulebbai S, Salam N, Md Salleh MS, et al. Antioxidant protective effect of glibenclamide and metformin in combination with honey in pancreas of streptozotocin-induced diabetic rats. Int J Mol Sci 2010;11:2056-66.

19. Owolabi OJ, Omogbai EKI. Co-administration of glibenclamide and amlodipine induces resistance to hyperglycemic treatment in streptozotocin-induced adapted/non-adapted diabetic rats. Clin Exp Pharmacol 2011;1:1-7.

20. Ibegbulem CO, Eyong EU, Essien EU. Biochemical effects of drinking Terminalia catappa Linn. decoction in wistar rats. Afr J Biochem Res 2011;5:237-43.

21. Cabrera C, Artacho R, Giménez R. Beneficial effects of green teaa review. J Am Coll Nutr 2006;25:79-99.

22. Iwai K, Kim MY, Onodera A, Matsue H.Alpha-glucosidase inhibitory and antihyperglycemic effects of polyphenols in the 
fruit of Viburnum dilatatum Thunb. Agric Food Chem 2006;54:4588-92.

23. Iwai K. Antidiabetic and antioxidant effects of polyphenols in brown alga Ecklonia stolonifera in genetically diabetic KK-A(y) mice. Plant Foods Hum Nutr 2008;63:163-9.

24. Ali H, Houghton PJ, Soumyanath A. Alpha-amylase inhibitory activity of some Malaysian plants used to treat diabetes; with particular reference to Phyllanthusamarus. J Ethnopharmacol 2006;107:449-55.

25. Tadera K, Minami Y, Takamatsu K, Matsuoka T. Inhibition of alpha-glucosidase and alpha-amylase by flavonoids. J Nutr Sci Vitaminol (Tokyo) 2006;52:149-53.

26. Salah EDR, Ma Q, Kandil ZA, El-Halawany AM. Triterpenes as uncompetitive inhibitors of $\alpha$-glucosidase from flowers of PunicagranatumL. Nat Prod Res 2014;28:2191-4.

27. Salehi P, Asghari1 B, Esmaeili MA, Dehghan H, Ghazi I. $\alpha-$ Glucosidase and $\alpha$-amylase inhibitory effect and antioxidant activity of ten plant extracts traditionally used in Iran for diabetes. J Med Plant Res 2013;7:257-66.

28. Sujith K, Darwin R, Roosewelt DRC. Antidiabetic activity of methanolic extract of Butea frondosa leaves with its possible mechanism of action. Asian J Pharm Clin Res 2011;4 Suppl 3:93-8.

29. Malini P, Kanchana G, Rajadurai M. Antidiabetic activity of ellagic acid in streptozotocin-induced diabetes mellitus in Albino Wistar rats. Asian J Pharm Clin Res 2011;4 Suppl 3:124-8.

30. Gandhi GR, Sasikumar P. Antidiabetic effect of Merremia emarginata Burm. F. in streptozotocin induced diabetic rats. Asian Pac J Trop Biomed 2012;2:281-6.

31. Mohan Y, Jesuthankaraj GN, Thangavelu NR. Antidiabetic and antioxidant properties of Triticum aestivum in Streptozotocininduced diabetic rats. Adv Pharmcol Sci 2013:1-9. http://dx.doi.org/10.1155/2013/716073

32. Sampath V, Mani N. Novel approach of isolation of tannins from the fruit rind of Terminalia chebula and Punica granatum and its synergistic antidiabetic activity against streptozotocin induced diabetic rats. Int J Pharmacogn Phytochem Res 2015;7 Suppl 1:76-82.
33. Bahadoran Z, Mirmiran P, Azizi F. Dietary polyphenols as potential nutraceuticals in management of diabetes: a review. J Diabetes Metab Disord 2013;12:43.

34. Andulla B, Varadacharyulu NCH. Antioxidant role of mulberry leaves in streptozotocin-diabetic rats. Clin Chim Acta 2003;338 Suppl 1-2:3-10.

35. Howarth FC, Jacobson M, Shafiullah M, Adeghate E. Long-term effects of streptozotocin-induced diabetes on the electrocardiogram, physical activity and body temperature in rats. Exp Physiol 2005;90 Suppl 6:827-35.

36. Chen L, LaRocque LM, Efe O, Wang J, Sand JM, Klein JD. Effect of dapagliflozin on fluid and electrolyte balance in diabetic rats. Asian J Med Sci 2016;352 Suppl 5:517-23.

37. Tanwar RS, Sharma SB, Singh UR, Prabhu KM. Attenuation of renal dysfunction by anti-hyperglycemic compound isolated from fruit pulp of Eugenia jambolana in streptozotocin induced diabetic rats. Ind J Biochem Biophys 2010;47 Suppl 2:83-9.

38. Akbar DH, Hagras MM, Amin HA, Khorshid OA. Comparison between the effect of glibenclamide and captopril on experimentally induced diabetic nephropathy in rats. J Renin Angiotensin Aldosterone Syst 2013;14 Suppl 2:103-15.

39. Dubey VK, Patil CR, Kamble SM, Tidke PS, Patil KR, Maniya PJ, et al. Oleanolic acid prevents progression of streptozotocin induced diabetic nephropathy and protects renal microstructures in sprague dawley rats. J Pharmacol Pharmacother 2013;4 Suppl 1:47-52.

40. Diniz LRL, Portella VG, Cardoso FM, Souza MA, Caruso-Neves C, Cassali GD, et al. The effect of saponins from Ampelozizyphus amazonicus Ducke on the renal Na+pump's activities and urinary excretion of natriuretic peptides. BMC Complementary Altern Med 2012;11 Suppl 12:1-7.

\section{How to cite this article}

- Tapan Behl, Anita Kotwani. Anti-hyperglycemic effect of terminalia catappa fruit extract in streptozotocin-induced diabetic rats. Int J Pharm Pharm Sci 2017;9(4):212-217. 